\title{
A shocking craniofacial penetrating injury by a steel bar
}

\author{
Po Yuan Chen, M.D.,, ${ }^{1}$ Sheng Fa Yao, M.D., ${ }^{2}$ An Xiu Dai, M.D., ${ }^{3}$ \\ Han Jung Chen, M.D., ${ }^{1}$ Kuo Wei Wang, M.D. ${ }^{1}$
}

\author{
1'Department of Neurosurgery, E-da Hospital, I-shou University, Kaohsiung, Taiwan; \\ ${ }^{2}$ Department of Plastic Surgery, E-da Hospital, I-shou University, Kaohsiung, Taiwan; \\ ${ }^{3}$ Department of Otolaryngology, E-da Hospital, I-shou University, Kaohsiung, Taiwan
}

\begin{abstract}
Owing to the diversity in cause and damage, there is no standard surgical treatment method for a complicated penetrating craniofacial injury. The treatment of a complicated penetrating head injury caused by a steel bar is presented here. A 66-year-old woman fell onto a steel bar at a construction site and it penetrated the mandible, entered the sinus and orbital cavities, and reached the base of the frontal bone. A multi-disciplinary team including a neurosurgeon, otolaryngologist, and plastic surgeon was involved in removing the steel bar. The patient survived without sequelae except for blindness in the right eye. Despite the lack of standardized surgical treatment for a complicated penetrating craniofacial injury, aggressive treatment by a multidisciplinary team can result in good outcomes.
\end{abstract}

Key words: Cerebrospinal fluid leak; foreign bodies; mandibular injuries; orbital fractures.

\section{INTRODUCTION}

Owing to the diversity in mechanisms and patterns, there is no standard surgical treatment method for a complicated penetrating craniofacial injury. The treatment of a complicated penetrating head injury caused by a steel bar is presented here.

\section{CASE REPORT}

A 66-year-old woman fell onto a steel bar at a construction site and maintained consciousness. The steel bar penetrated upwardly from the left submandibular area (Fig. I) and was viewable in the oral cavity. The bar limited the patient's head and neck movements. A slight degree of exophthalmos was observed on the right side. She was brought directly to our emergency department.

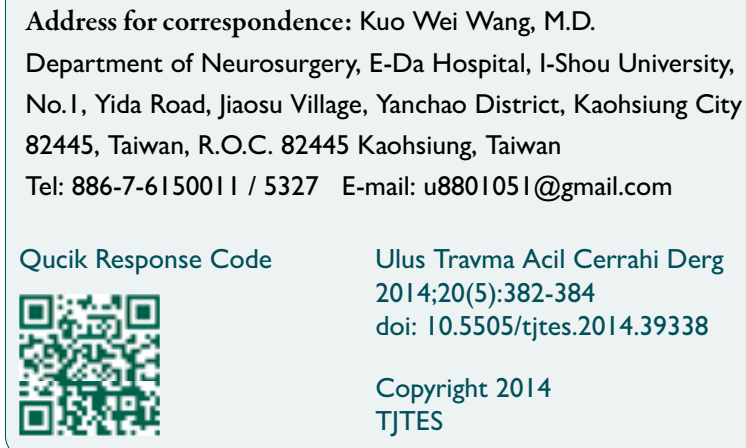

The brain computed tomography (CT) scan with a 3-dimensional reconstruction revealed a metallic foreign body penetrating the head from the left submandibular space through the right orbital roof to the right sub frontal lobe (Figs. 2a, b).

Following consultation, the steel bar was removed in the following order by a multidisciplinary team including a neurosurgeon, otolaryngologist, and plastic surgeon. The neurosurgeon performed bicoronal craniotomy and deep dissection in the right frontal base to expose the tip of the steel bar. The otolaryngologist performed multiple sinusectomy with inferior turbinectomy of the right side to expose the intranasal section of the steel bar. The plastic surgeon pulled the steel bar out under the supervision of the neurosurgeon, who visually monitored the frontal base, and the otolaryngologist, who used an endoscope to view the nasal sinus. This step was performed to prevent active bleeding and enable direct action in case of bleeding. Fortunately, no injuries occurred in major vessels resulting in active bleeding.

A perforated hole in the base of the right frontal bone was observed with a small amount of cerebrospinal fluid (CSF) leakage through the torn dura.

Following debridement, the dura was repaired, and the skull defect was covered with a rotational muscle flap from the right temporalis muscle. A dural sealant was sprayed on the dura and the muscle flap. The otolaryngologist performed 


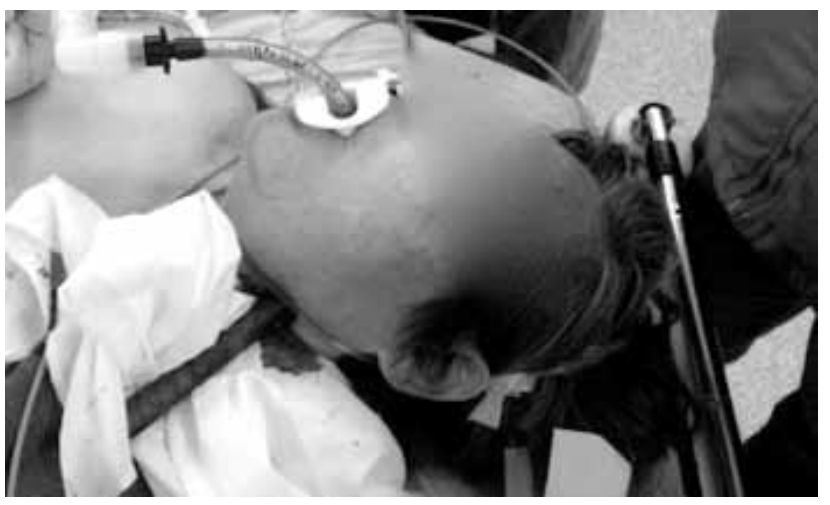

Figure 1. A view of the patient with the steel bar penetrating the head upwardly from the left submandibular area.

debridement and hemostasis, and the plastic surgeon performed submandibular debridement, applied wet dressing, and closed the wound one week later. Finally, preventive tracheostomy was performed and the tube was removed without any complications one month later. Antibiotics (vancomycin and ceftriaxone) were administered for ten days to prevent possible infection. The patient survived without sequelae except for blindness of the right eye.

\section{DISCUSSION}

A variety of unusual cranial penetrations have been reported until today. ${ }^{[I]}$ The goals of treatment are removal of the for- eign body for decompression, debridement to prevent and treat infection, prevention of vascular injury to all possible extents, and achieving hemostasis for repair of the dura for prevention of CSF leaks. ${ }^{[2]}$

Our patient received a multidisciplinary surgical intervention resulting in good recovery. During the two-year follow up period, no CSF leaks, seizures, or formation of brain abscesses were noted. The recommendations in the literature regarding antibiotic treatment $(>7 \text { days of treatment })^{[3]}$ were followed with the administration of antibiotics for ten days. This led, in part, to the success of the intervention.

Our approach could have been improved by a pre-operative angiography or a CT-angiography recommended for the evaluation of the possibility of vascular injury. ${ }^{[3-5]}$ Although these types of preoperative imaging study were not performed, we visually observed the area surrounding the trajectory of the steel bar, and we were confident that there was no major vasculature in contact with the steel bar before its removal.

The intervention may have also benefited from an intraoperative consultation with an ophthalmologist. The preoperative consultation with the ophthalmologist resulted in a diagnosis of blindness in the right eye. In our case, an intraoperative consultation was not likely to change this outcome. However, the outcomes may be different for other patients.
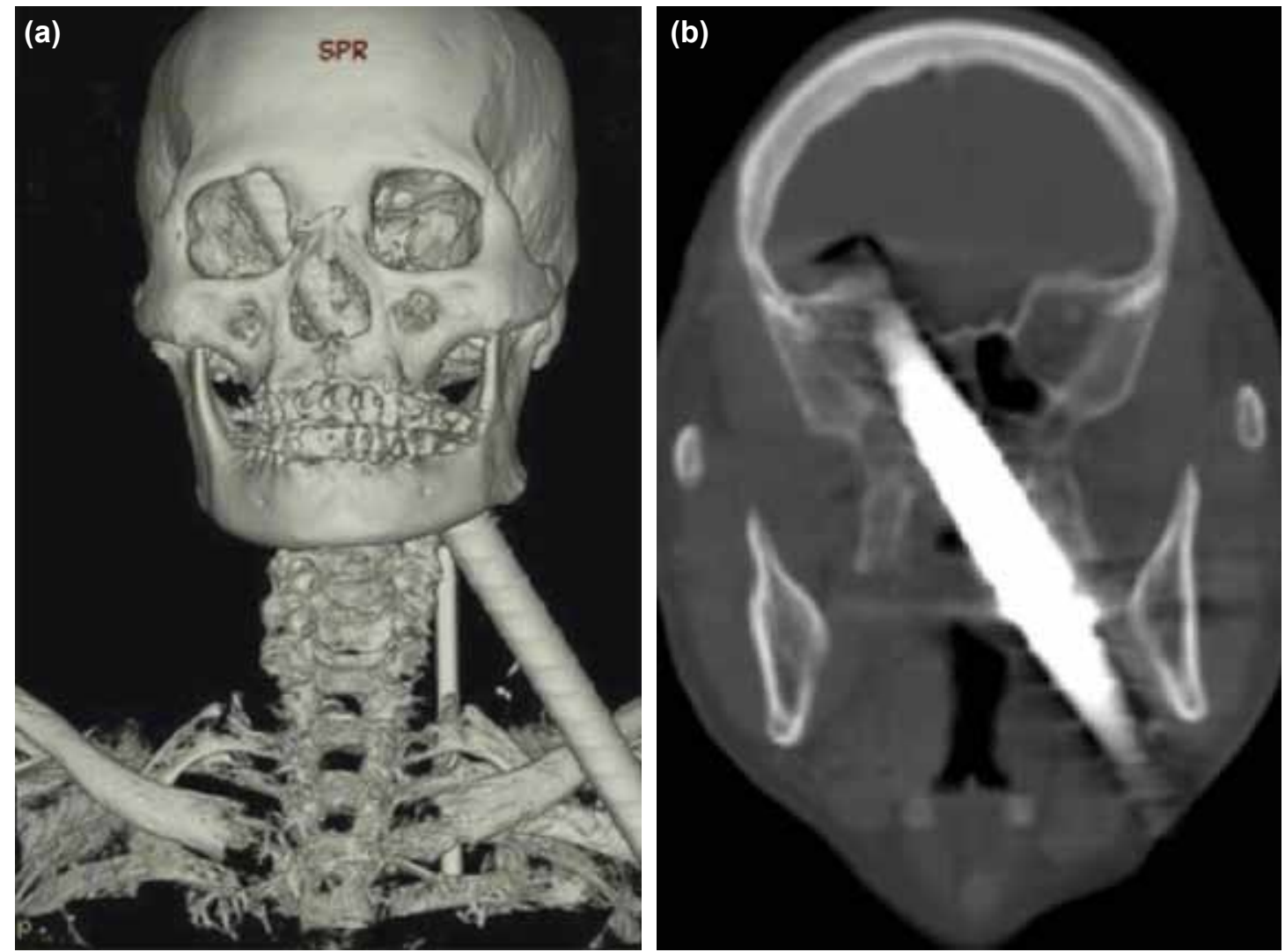

Figure 2. (a) A 3-dimensional computed tomography scan showing the trajectory of the steel bar. (b) A coronal view of the brain computed tomography scan showing the steel bar penetrating to the base of the right frontal bone. 
Hybrid treatment using surgery and an intraoperative endovascular intervention has also been suggested. ${ }^{[2]}$ This type of treatment requires a hybrid operating room, which is not available in our hospital. The benefit to our patient would have been minimal in the absence of bleeding in any major vessels.

The general treatment guidelines for a penetrating craniofacial injury are to decompress, debride, and avoid neurovascular injury and the subsequent complications. A multidisciplinary surgical intervention is always required, particularly in the absence of a standard surgical method. Instead, the surgical approach must be tailored according to the mechanisms, patterns, and materials of the injury. By sharing our treatment experience of this unique and shocking case of a penetrating injury, we hope that it can be used as a reference if other similar injuries are encountered.

\section{Acknowledgements}

There were no grants or other financial or material support.

\section{REFERENCES}

1. Bartholomew BJ, Poole C, Tayag EC. Unusual transoral penetrating injury of the foramen magnum: case report. Neurosurgery 2003;53:989-91.

2. Natrella M, Duc L, Lunardi G, Cristoferi M, Fanelli G, Meloni T. Treatment of a transorbital penetrating injury: a particular endovascular approach. Interv Neuroradiol 2012;18:191-4.

3. Kazim SF, Bhatti AU, Godil SS. Craniocerebral injury by penetration of a T-shaped metallic spanner: A rare presentation. Surg Neurol Int 2013;4:2. CrossRef

4. Skoch J, Ansay TL, Lemole GM. Injury to the Temporal Lobe via Medial Transorbital Entry of a Toothbrush. J Neurol Surg Rep 2013;74:23-8.

5. Offiah C, Hall E. Imaging assessment of penetrating injury of the neck and face. Insights Imaging 2012;3:419-31. CrossRef

\section{OLGU SUNUMU - ÖZET}

\section{Çelik parmaklık üstüne düşme sonucu oluşan şok edici kraniyofasiyal penetran travma}

\section{Dr. Po Yuan Chen, ${ }^{1}$ Dr. Sheng Fa Yao, ${ }^{2}$ Dr. An Xiu Dai, ${ }^{3}$ Dr. Han Jung Chen, ${ }^{1}$ Dr. Kuo Wei Wang}

${ }^{1} I$-shou Üniversitesi, E-da Hastanesi, Nöroşirurji Anabilim Dalı, Kaohsiung, Tayvan;

2I-shou Üniversitesi, E-da Hastanesi, Plastik Cerrahi Anabilim Dalı, Kaohsiung, Tayvan;

${ }^{3}$ I-shou Üniversitesi, E-da Hastanesi, Kulak Burun Boğaz Anabilim Dalı, Kaohsiung, Tayvan

Etiyoloji ve hasarlanmada oluşan farklılıklar nedeniyle komplike penetran yaralanmaların standart bir cerrahi tedavi yöntemi yoktur. Burada çelik parmaklık üstüne düşme sonucu oluşmuş komplike bir penetran kafa travmasının tedavisi sunuldu. Bu yazıda, inşaat sahasında çelik parmaklığın üzerine düşen 66 yaşındaki kadın hasta sunuldu. Alt çenesi, sinüs ve göz çukuruna giren çelik çubuk alın kemiğinin tabanına kadar ilerlemişti. Beyinsinir, kulak-burun-boğaz ve plastik cerrahlardan oluşan çok uzmanlı bir ekip çelik çubuğu çıkardı. Hasta sağ gözünde körlük dışında herhangi bir sekeli olmadan sağ kurtuldu. Komplike penetran kraniyofasiyal yaralanmanın standartlaşmış bir cerrahi tedavisi olmamasına rağmen çok uzmanlı bir ekiple agresif tedavi iyi sonuçlar sağlayabilmektedir.

Anahtar sözcükler: Serebrospinal sıvı kaçağı; yabancı cisimler; mandibular yaralanmaları; orbita kırıkları.

Ulus Travma Acil Cerrahi Derg 2014;20(5):382-384 doi: 10.5505/tjtes.20।4.39338 